\title{
Esquirol-Séguin-Down Syndrome Associated with Atrial Septal Defect plus Tricuspid Regurgitation
}

\section{Aamir Jalal Al-Mosawi}

Advisor doctor and expert trainer: Baghdad Medical City and the National Training and Development Center Iraqi Ministry of Health. Baghdad, Iraq

*Corresponding Author: Aamir Jalal Al-Mosawi, Advisor doctor and expert trainer Baghdad Medical City and the National Training and Development Center Iraqi Ministry of Health, Baghdad, Iraq.

Received date: November 19, 2021; Accepted date: December 08, 2021; Published date: January 03, 2022

Citation: Aamir Jalal Al-Mosawi. (2022). Esquirol-Séguin-Down Syndrome Associated With Atrial Septal Defect Plus Tricuspid Regurgitation. Cardiology Research and Reports. 4(1); DOI: 10.31579/2692-9759/033

Copyright: () 2022 Aamir Jalal Al-Mosawi, This is an open-access article distributed under the terms of the Creative Commons Attribution License, which permits unrestricted use, distribution, and reproduction in any medium, provided the original author and source are credited.

\begin{abstract}
Background: Esquirol-Séguin-Down syndrome (Trisomy 21) was first described by Jean-Etienne Dominique Esquirol in 1838 and later by Edouard Séguin in 1846. Thereafter, in 1862, John Langdon Down, a British physician emphasized that the syndrome is a distinct form of mental retardation. Congenital cardiac defects are observed in more than one third of the patients with Esquirol-Séguin-Down syndrome, and in approximately 80\% these cardiac defects are atrioventricular septal defect or ventricular septal defect with the former being more common. The association of Esquirol-Séguin-Down syndrome with atrial septal defect plus tricuspid regurgitation has been rarely reported. The aim of this paper is to report the rare association of Esquirol-Séguin-Down syndrome with atrial septal defect plus tricuspid regurgitation.
\end{abstract}

Patients and methods: Two and half years old boy with Esquirol-Séguin-Down syndrome, developmental delay and abnormal echocardiography was studied, and the recent relevant literatures were reviewed.

Results: Dysmorphic facial features included hypertelorism, oblique palpebral fissures, epicanthic folds, depressed nasal bridge and low set ears. Echocardiography showed atrial septal defect with tricuspid regurgitation.

Conclusion: This paper reports the first case of Esquirol-Séguin-Down syndrome in Iraq associated with atrial septal defect plus tricuspid regurgitation.

Keywords: esquirol-séguin-down syndrome; atrial septal defect; tricuspid regurgitation

\section{Introduction}

Esquirol-Séguin-Down syndrome (Trisomy 21) was first described by Jean-Etienne Dominique Esquirol (Figure-1A) in 1838 and later by
Edouard Séguin (Figure-1B) in 1846. Thereafter, in 1862, John Langdon Down (Figure-1C), a British physician, emphasized that the syndrome is a distinct form of mental retardation. The syndrome was recognized as a chromosome 21 trisomy by Dr Jérôme Lejeune (Figure1D) in 1959, and the condition became known as trisomy 21[1].

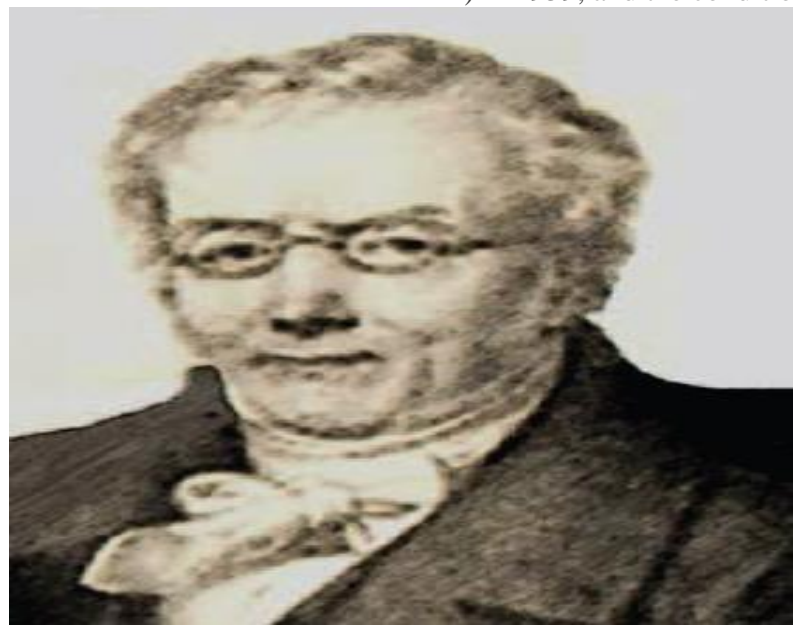




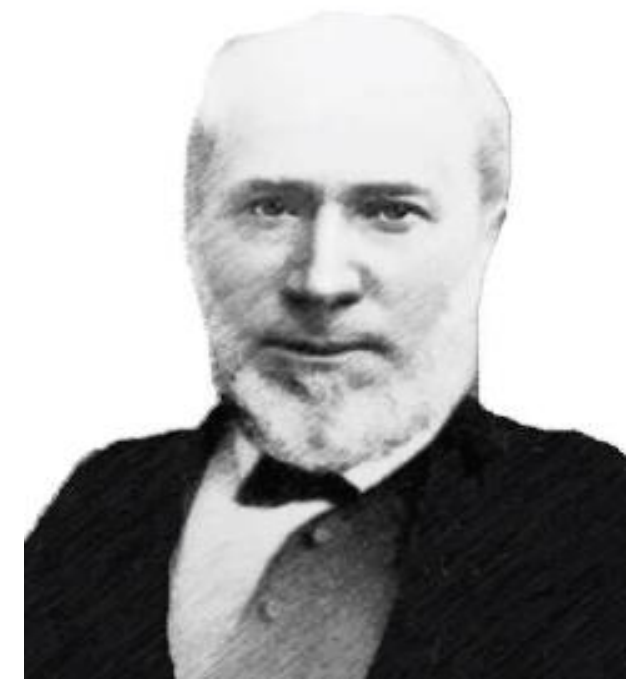

Figure-1B: Edouard Séguin (January 20, 1812-October 28, 1880), a physician and educationist born in Clamecy, Nièvre, France. He was best known for his work with children with cognitive impairments in France and the United States

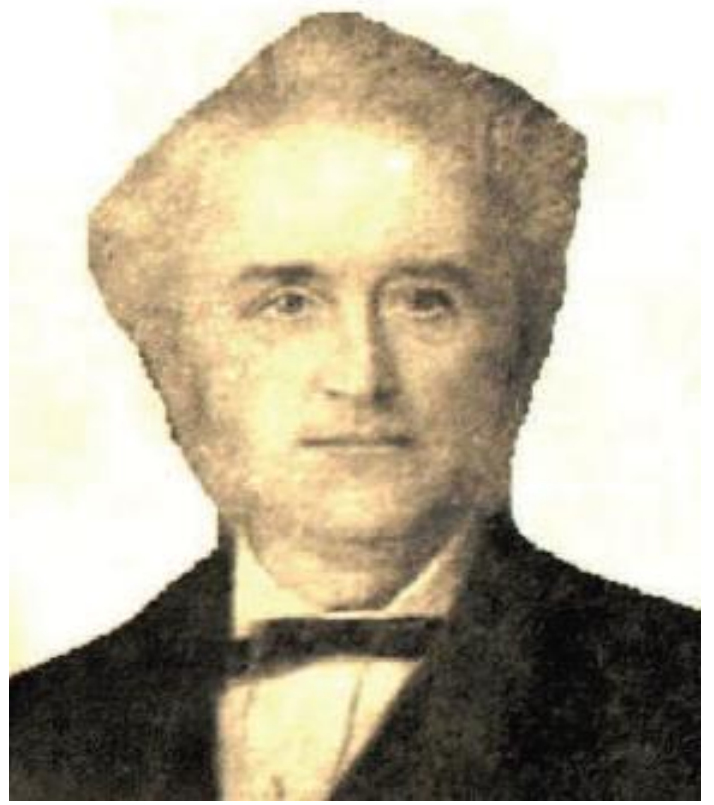

Figure-1C: John Langdon Down (18 November, 1828-7 October, 1896), a British physician

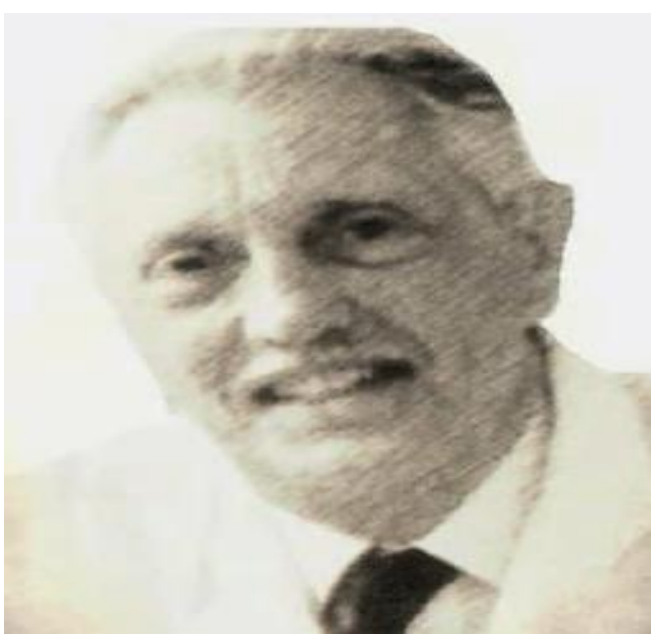

Figure-1D: Jérôme Jean Louis Marie Lejeune (13 June, 1926-3 April, 1994) was a French pediatrician and geneticist, best known for discovering the link of diseases to chromosome abnormalities and for his subsequent opposition to prenatal diagnosis and abortion. 
Congenital cardiac defects are observed in more than one third of the patients with Esquirol-Séguin-Down syndrome, and in approximately $80 \%$ these cardiac defects are atrioventricular septal defect or ventricular septal defect with the former being more common. The association of Esquirol-Séguin-Down syndrome with atrial septal defect plus tricuspid regurgitation has been rarely reported $[1,2,3]$. The aim of this paper is to report the rare association of Esquirol-Séguin-Down syndrome with atrial septal defect plus tricuspid regurgitation.

\section{Patients and methods}

Two and half years old boy with Esquirol-Séguin-Down syndrome, developmental delay (Figure-2) and abnormal echocardiography was studied, and the recent relevant literatures were reviewed.

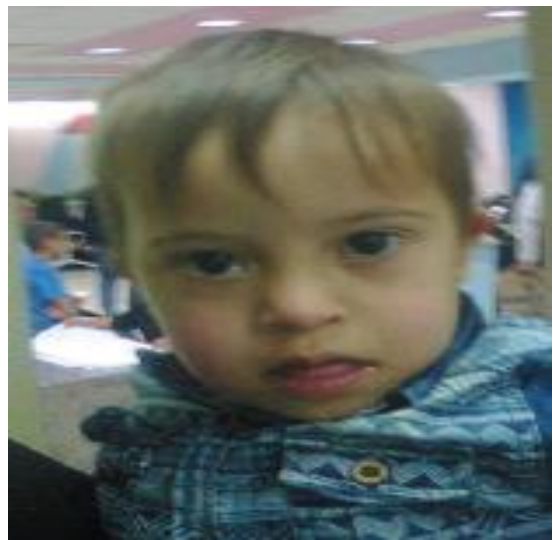

Figure-2: Two and half years old boy with Esquirol-Séguin-Down syndrome

\section{Results}

Dysmorphic facial features included hypertelorism, oblique palpebral fissures, epicanthic folds, depressed nasal bridge and low set ears (Figure-3). The mother was at the age of 39 when he was born. He didn't show social smile until the of two years. He can only walk with support. Before about two years he started saying Baba and Mama. The echocardiography showed atrial septal defect with tricuspid regurgitation (Figure-4).

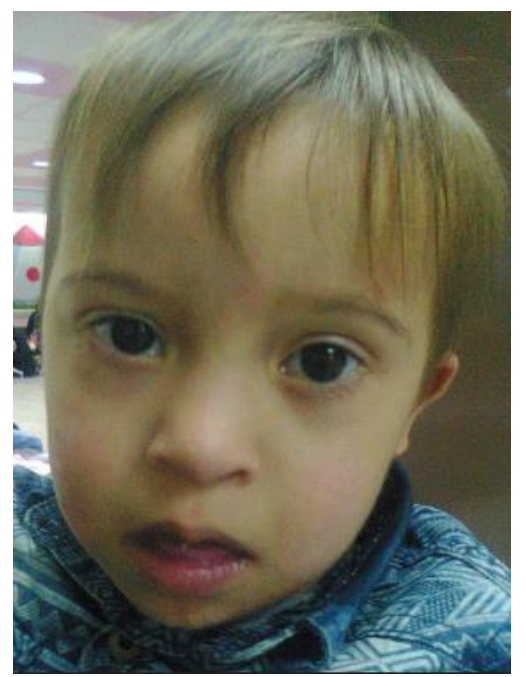

Figure-3: Dysmorphic facial features included hypertelorism, oblique palpebral fissures, epicanthic folds, depressed nasal bridge and low set ears

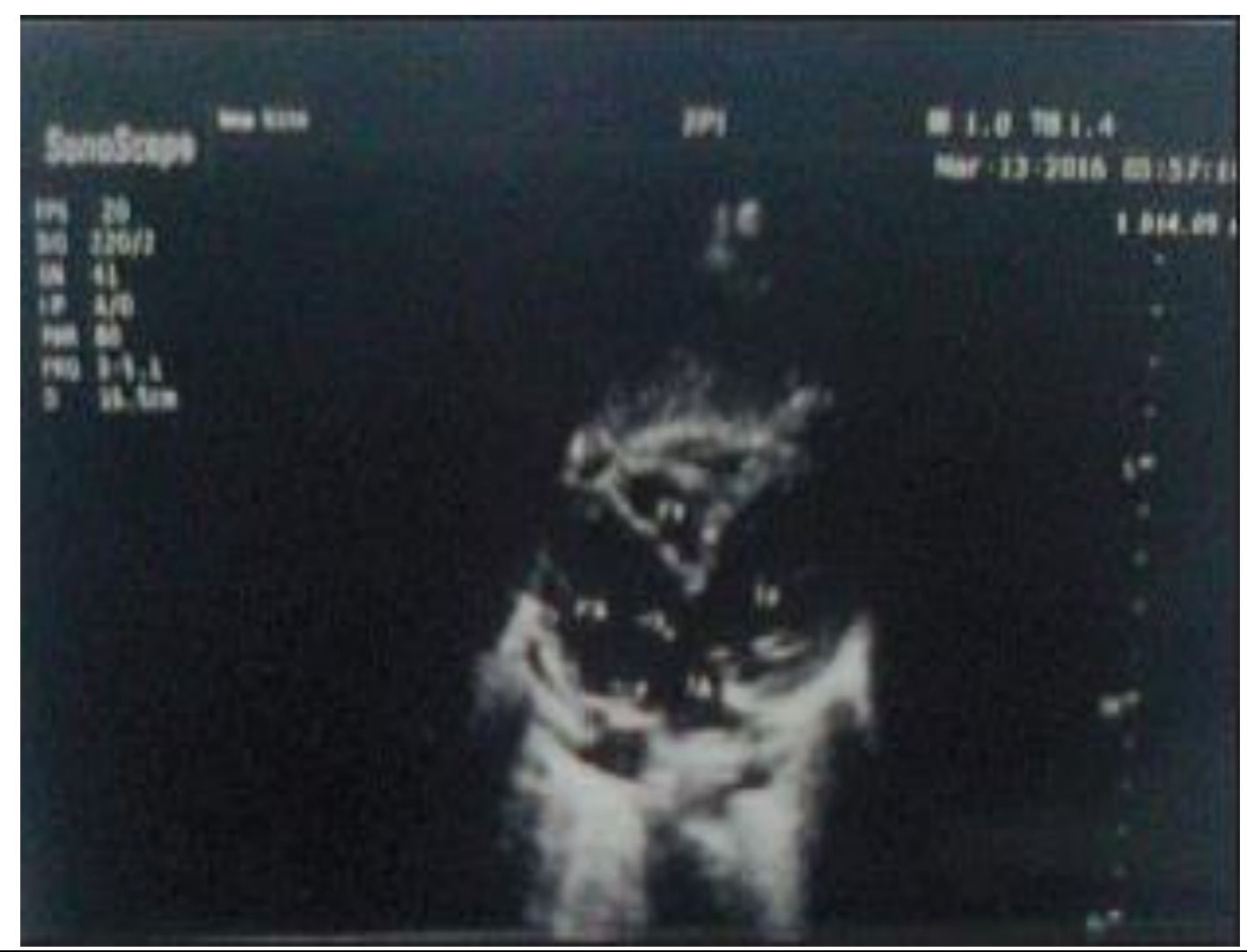

Figure-4A: The echocardiography of a boy with Esquirol-Séguin-Down syndrome showing atrial septal defect with tricuspid regurgitation 


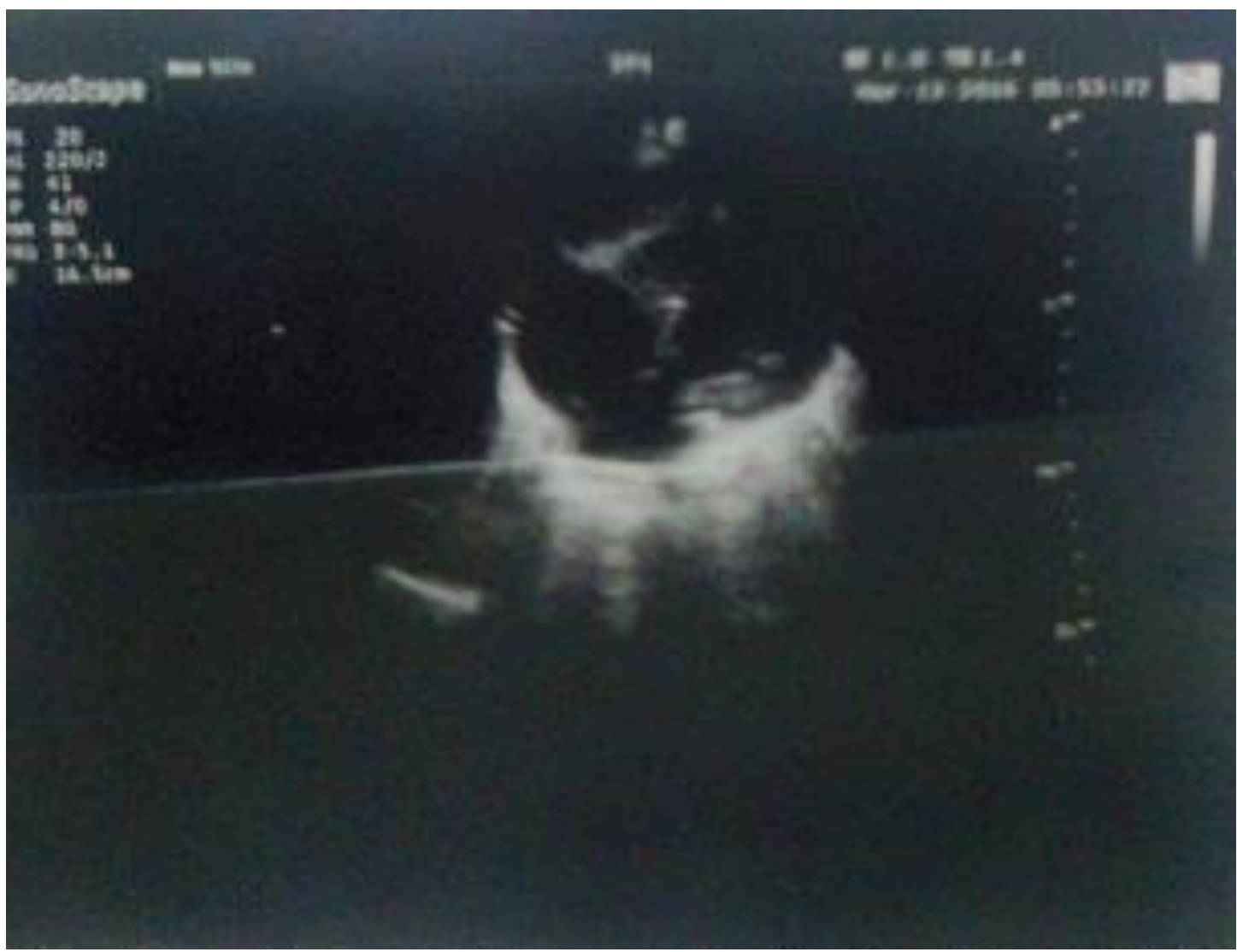

Figure-4B: The echocardiography of a boy with Esquirol-Séguin-Down syndrome showing atrial septal defect with tricuspid regurgitation

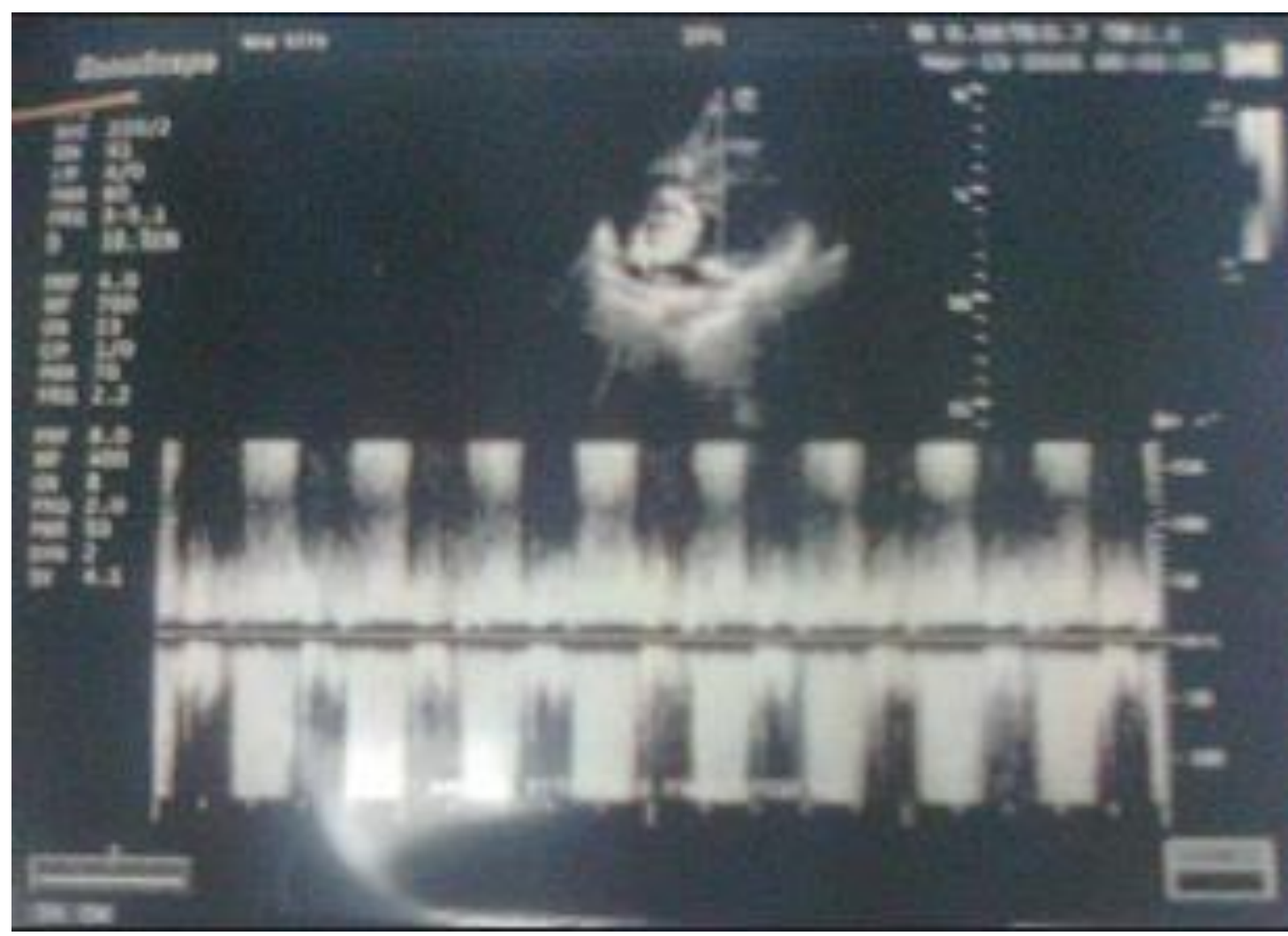

Figure-4C: The echocardiography of a boy with Esquirol-Séguin-Down syndrome showing atrial septal defect with tricuspid regurgitation 


\section{Discussion}

Esquirol-Séguin-Down syndrome is the most common chromosomal disorder in humans. It is caused by the presence of a third copy of chromosome 21 or part of it. It is the second most common cause of mental retardation in Iraqi children after idiopathic mental retardation, accounting for $8.75-19 \%$ ) of cases of mental retardation. The syndrome is associated with characteristic facial features, mental and growth retardation. The oblique eye fissures with epicanthic mongoloid skin folds on the inner corner of the eyes made the disorder originally called mongolism $[1,4,5]$.

Benhaourech et al (2016) from Morocco reported 128 patients with Esquirol-Séguin-Down syndrome and congenital heart defects including 186 lesions. The most common cardiac defect was atrioventricular septal defect which accounted for $29 \%$ of all lesions, followed by ventricular septal defect which accounted for $21.5 \%$ of all lesions, and atrial septal defect which accounted for $19.9 \%$ of all lesions. The most common combination of congenital cardiac defects were atrioventricular septal defect atrial septal defect (10\%) and ventricular septal defect plus atrial septal defect (7.8\%) [3].

\section{Conclusion}

This paper reports the first case of Esquirol-Séguin-Down syndrome in Iraq associated with atrial septal defect plus tricuspid regurgitation.

\section{Acknowledgement}

The author would like to express his gratitude for the parents of the child who willingly accepted publishing his photos.

Some of the figures in this paper were included in author's previous publication, but the author has their copyright.

\section{Conflict of interest: None.}

\section{References}

1. Al-Mosawi AJ (2018). Down syndrome Atlas. $1^{\text {st }}$ ed., Saarbrücken; LAP Lambert Academic Publishing: (ISBN: 978613-9-58120-7).

2. Malt EA, Dahl RC, Haugsand TM, Ulvestad IH, Emilsen NM, Hansen B, Cardenas YE, Skøld RO (2013). Health and disease in adults with Down syndrome. Tidsskr Nor Laegeforen. Feb 5; 133(3):290-4. English, Norwegian. Doi: 10.4045/tidsskr.12.0390. PMID: 23381164.

3. Benhaourech S, Drighil A, Hammiri AE (2016).Congenital heart disease and Down syndrome: various aspects of a confirmed association. Cardiovasc J Afr Sep/Oct; 27(5):287-290. Doi: 10.5830/CVJA-2016-019. PMID: 27805241.

4. Al-Mosawi AJ (2019). The etiology of mental retardation in Iraqi children. SunKrist Journal of Neonatology and Pediatrics June 21; 1(1):1-9. Article No: sjnp-v1-1001. Doi:10.46940/sjnp.01.1001Doi: 10.5281/ zenodo. 3878451

5. Al-Mosawi AJ (2019). The pattern of mental retardation in Iraqi children. $1^{\text {st }}$ ed., Saarbrücken; LAP Lambert Academic Publishing: (ISBN: 978-613-9-47350-2).
This work is licensed under Creative Commons Attribution 4.0 License
To Submit Your Article Click Here: Submit Manuscript

DOI: $10.31579 / 2692-9759 / 033$
Ready to submit your research? Choose Auctores and benefit from:

$>$ fast, convenient online submission

$>$ rigorous peer review by experienced research in your field

$>$ rapid publication on acceptance

$>$ authors retain copyrights

$>$ unique DOI for all articles

$>$ immediate, unrestricted online access

At Auctores, research is always in progress.

Learn more https://auctoresonline.org/journals/cardiology-research-andreports- 